\title{
WhatsApp and English Learning: Students' Perceptions and Challenges in Pandemic Era
}

Rena Juliana

Department of English Education, Sekolah Tinggi Agama Islam Negeri Teungku Dirundeng Meulaboh, Aceh Barat, Indonesia

email: renajuliana@staindirundeng.ac.id

Received:

May 02, 2021

Revised:

May 31, 2021

Accepted:

June 26, 2021

\section{ABSTRACT}

Since the pandemic era due to Covid-19, WhatsApp has become an application that is widely used for online learning. In the new normal era, WhatsApp was still the application most widely used by lecturers and students because sending teaching materials was easy and fast. This study investigated students' perceptions and challenges of utilizing WhatsApp in English language learning amid the pandemic era. The method used was a qualitative method. The researcher used a purposive sampling technique in selecting the participants. The participants in this study amounted to 12 EFL students of 2nd semester of STAIN Teungku Dirundeng Meulaboh. A semi-structured interview was used as data collection techniques. The interview data were analyzed using the Miles and Huberman flow model. The results showed that students used social media to learn and improve their English skills. WhatsApp is the most used application, considered fun, comfortable, helpful, and easy to use. WhatsApp is not only effective and time-saving, it also motivates students in learning English. In addition, WhatsApp uses less internet quota than other online applications. Even so, the internet connection, internet quota, and storage capacity on their devices are still challenges for the students. It can be concluded that the students have positive perceptions of using WhatsApp to learn English.

Keywords: Whatsapp; English Learning; Perceptions; Challenges; Pandemic Era

\section{INTRODUCTION}

Coronavirus disease 2019 (Covid-19) remains a big and serious problem in all parts of the world. Since it started in the city of Wuhan, China in late December 2019, it has spread to almost all parts of the world. It spreads so quickly that it attacks anyone contaminated with deadly effects. It has changed the way people live in social, economic, political, and educational terms.

The educational world is currently facing challenges to improve the quality of education in all conditions. The government continues to update guidelines to reduce the spread of Covid-19. New guidelines are also being implemented in the world of education. Government advice to stay home and engage in activities from home during the pandemic must be followed to break the chain of the spread of Covid-19. Therefore, changing learning methods, which usually take place in the classroom, is enough to learn from home or from what is known as online learning.

Work from home (WFH) is one of the government's policies by introducing an online learning system in the education aspect that addresses lecturers and students to 
reduce the virus spreads (Suadi, 2021:52). The Covid-19 pandemic is forcing universities around the world to shift their education from in-person learning to online learning through the use of information and communication technology (ICT).

The weakness of the online learning system is not only due to educators who do not fully master the technology, but there are still many students who do not have online media facilities so the government issued a new policy regarding the learning system. In early July 2020, the government implemented the new normal. Learning in this phase differs from normal learning. Educators need to improve their competence to master different types of creative and innovative learning methods according to the needs of their conditions.

In order to provide authentic materials to students, Muslem, Yusuf, and Juliana (2018:5) stated that ICT is mostly used by lecturers. Students can improve their speaking, listening, reading, and writing skills through the use of ICT. In addition, the result of their research was that ICT supported the teaching and learning process even with limited time and tools, and also the problem of poor internet connection and lack of knowledge and experience in using ICT.

Students and lecturers need to be familiar with both technology and applications that support teaching and learning activities. The technologies considered as effective tools are computers, laptops, mobile phones, smart phones, and the internet (Ta'amneh, 2017). Pratama, Azman, Kassymova, and Duisenbayeva (2020:61) described some applications that can be used to support teaching and learning activities; they are Zoom, Google Meet, WhatsApp, Facebook, and others.

Cell phone technology is considered to be the most potent tool that can be used for teaching English. Most EFL instructors, lecturers and teachers, use the messaging application for mobile phones and smartphones. The most popular messaging application is WhatsApp (Jasrial, 2018:151). In addition, Nihayati and Indriani (2021:44) explained that many applications are developed and web-based. One of them that has grown and become famous is WhatsApp. WhatsApp is a web-based mobile and social network application that is built into various functions that are used to communicate with other users. These range from education, business, and entertainment developed by this social networking website.

Teaching English in a pandemic era is very challenging. This forces lecturers to offer creatively interesting activities to involve students in the learning process. The presence of learning devices also plays an important role in helping them support the teaching and learning process. Implementing WhatsApp in English classrooms offers many opportunities to help students learn English in the best possible way. In general, in addition to providing interest in student learning, using WhatsApp provides numerous opportunities to practice English regularly without being constrained by time and class meetings. WhatsApp functions: Emojis, images, audio, links, documents, create groups and text can be used optimally in English learning. During the implementation of WhatsApp Group learning activities, students gave a positive answer (Dewi, 2019:170).

WhatsApp is a simple application. Students can easily practice English only through their smartphone without using any paper. Lecturers can also use the application to present their teaching materials such powerpoint presentations without wasting time to install a projector and laptop to display. By using this application, students can practice their English not only in the classroom but also at home and lecturers can easily monitor their works through it. 
While social media such as WhatsApp was not created directly for educational purposes, it has caught the attention of educators, especially in the field of English teaching. Several studies have been done to see if WhatsApp can be used in English classrooms. Umar (2021:2097) stated that during the pandemic, compared with the other applications, WhatsApp was more effective and interactive in the learning process. Pratama, Azman, Kassymova, and Duisenbayeva (2020:61) also added that WhatsApp is not only the most popular application, but also easy for sharing photos, audio, documents, and videos both for individuals or groups. WhatsApp is considered to be an appropriate application for students and lecturers to use as learning media to support teaching-learning activities.

Cetinkaya (2017:69) conducted a study on the effects of using WhatsApp on success in the educational process. The results of the study showed that WhatsApp had a positive impact on the success and its use was essentially welcomed. It cannot be denied that as a natural and high-quality educational technology, WhatsApp technology has the potential to contribute to education as assistive technology.

Ajid, Reni, Yunita, and Dwi (2018:29) see students as inextricably linked to their smartphones. They do a lot of things with their phones, like sending text, audio, and video, or just surfing the web. Collaborative learning, for example combining student collaboration with the use of mobile applications such as WhatsApp, can optimize smartphone functions, which makes the teaching and learning process much easier for students and lecturers. In addition to integrating WhatsApp into their education, which will be easy, fun, and useful, students will also receive positive learning intentions related to using WhatsApp in the learning process.

Jasrial (2018:153) explained that WhatsApp is a very effective and interesting tool for teaching English language. Besides several features that allow the users to send, chat, speak, write, and share many things in a chat room, WhatsApp has also interesting emoticons. Students are happy to use the emoticons to represent their feeling while chatting. WhatsApp is an easy and interesting application to be accessed by lecturers, students, and all ages and backgrounds anytime and anywhere.

WhatsApp interactions in learning are described in three main ways, namely interactions between lecturers or teachers, students and students, and students and content. Therefore, the challenges are divided into two areas: device connectivity and network connectivity (Thaariq, 2020:87). However, In Indonesia, a slow-speed internet connection is still an obstacle to online learning. Lecturers should concern about students' situations such as internet connection, internet quota, and teaching materials that consume a bit internet quota. The selection of online learning applications that support teaching and learning activities is very important (Farmurlasih, 2020:119). Besides the government provided internet quota for students and lecturers, compare to other online applications, WhatsApp takes a bit of internet quota. It is one of the reasons WhatsApp becomes afavorite online application for students.

Almost all of the study results support the use of WhatsApp to increase student learning and excitement. In addition, using WhatsApp can help students develop their English proficiency, expand their vocabulary, and learn from their friends' mistakes (Hamad, 2017: 74). In line with it, Famurlasih (2020:119) also stated that WhatsApps can help the students in gaining new vocabularies and four English skills.

Bensalem (2018: 32) found in his study, which examined the efficiency of learning vocabulary among EFL students, that the use of WhatsApp significantly increases the learning of vocabulary by students compared to conventional methods. In 
addition, using WhatsApp as a learning tool was a positive experience for most of the participants as it increased their motivation to learn.

When lecturers use WhatsApp as media in the English classroom to improve students' vocabulary, students can speak English more actively on WhatsApp and increase students' motivation to learn about the materials. Using the WhatsApp application enables students to immerse themselves in real conversations and receive instructions on mistakes made by their partners or members of their WhatsApp group. In addition, the lecturers need to develop learning activities that can turn students into active learners. This is a challenge for the lecturers to involve students so that they become active during teaching and learning activities using the WhatsApp application. In order to make the WhatsApp application a very useful tool in teaching and learning activities, one of the most important ways to make the learning more meaningful is material preparation before using various other methods to encourage students to be active (Afsyah, 2019:25).

Nurazizah, Frihatin, and Sugiarto (2019:343) in their research on the teaching and learning process of speaking through WhatsApp voice notes in class by speaking in narrative text. It was found that most of the students responded positively to the teaching and learning process. WhatsApp voice notes are seen as a useful tool for giving students the ability to talk about the narrative text in particular and making it easy for students to share information. Also, students can use English to ask for help. Learning to speak English with WhatsApp voice notes is an interesting learning activity and positive activity, and WhatsApp voice notes are easy to use.

When it comes to listening activities, the WhatsApp chat group has proven to be effective and effective for learning activities. The treatment in the form of audio postings and exercises in WhatsApp group chat had a significant influence on the students' listening comprehension. In addition, learning through "WhatsApp" encourages them to become more involved in the given exercises and increases their motivation to perform listening tasks that have been uploaded to the "WhatsApp group". This gives them more convenient and personal access as the material is on their device. In addition, students are more active and enthusiastic in performing student roles for learning to be successful (Setyowati, 2019:4).

The WhatsApp application is very easy and inexpensive to implement in reading comprehension as the students are familiar with WhatsApp. The steps to use WhatsApp in teaching reading comprehension are to set rules, create a unique name for WhatsApp groups, label reading comprehension activities, and give them feedback (Napratilora, Lisa, and Bangsawan, 2020:124). In addition, Alasmari (2019:46) showed relatively positive results in his research into the use of WhatsApp among young Saudi EFL students. Findings included that this mobile application helped students improve their reading skills and that students had good attitudes towards learning English after using WhatsApp.

A study conducted by Linda and Ri'aeni (2018:156) shows that WhatsApp Messenger attracts students so that students respond positively to using WhatsApp Messenger. Learning with WhatsApp groups is considered effective for encouraging students to write creatively. On the other hand, the results showed that almost all students actively learned to write recounting texts. Students can study outside of the classroom. WhatsApp can not only be used privately but also for educational purposes. Students can make positive use of their devices because of their ability to learn English. In addition, students can expand their knowledge of ICT learning. 
Kheryadi (2017: 12) taught English for six months by implementing WhatsApp and it was found that WhatsApp offers a lot of knowledge on how to best learn English for students. This application not only offers students an interest in learning but also offers them numerous opportunities to practice English regularly in group chats, without being restricted by time and class reunions. In addition, WhatsApp can inspire students to write and hide them from obstacles that can affect their learning performance, such as fear of failure or embarrassment to practice English. It can also help students build confidence, enthusiasm, and independence in studying and exploring their English skills. To get the best results when teaching English on WhatsApp, lecturers need to support students by educating them, either independently or independently and involving them in conversations. Also, they need to oversee the online chat process by providing adequate feedback so that using WhatsApp can increase motivation to improve students' English proficiency.

WhatsApp is the main tool for teaching and learning, which can be useful if the lecturer or teacher does not assign the students to many online tasks. Another learning benefit is providing timely online feedback on their students' online assignments. Since WhatsApp is widely used by Indonesian lecturers, teachers, and students, WhatsApp can be a suitable alternative for teaching and learning during the pandemic. The effective practice of implementing WhatsApp as the primary learning tool aligns student needs and skills with targeted teaching and assessment materials, combined with timely feedback to support students (Budianto and Arifani, 2021:285).

Based on the description above, assessing student perceptions and challenges regarding the use of social media, especially the WhatsApp application for learning English in the pandemic era, is important for research because lecturers assess student preferences regarding appropriate social media applications to use and how they use WhatsApp as a medium for English language learning. The study of students' perceptions on social media about learning English in Indonesia is relatively low. Therefore, this study was conducted to provide valuable information about how students in higher education use social media, what perceptions and challenges they face when using social media, particularly the WhatsApp application, to learn English in the pandemic era.

The focus of this research is to find out students' perceptions in higher education about the use of social media, particularly WhatsApp as a medium for learning English, including student behavior when using social media and the benefits of using social media. This study also focused on students' challenges in using WhatsApp to learn English in pandemic era.

Based on the aforementioned research background, the researcher formulated two research questions. The first is how students perceive them using WhatsApp to learn English? and the second is what are the benefits and challenges of students using WhatsApp to learn English?

The research results are intended to provide information for various parties. For English lecturers or teachers, the results of this study should provide information and suggestions for using social media like WhatsApp while learning English, especially during the pandemic, as social media is believed to have many benefits for improving students' English proficiency. In addition, the explanation of the students' responses in this study is expected to attract the attention of any English lecturer or teacher who may wish to use WhatsApp. Students are expected to use the learning outcomes to motivate them to learn English as English is an important skill for their future careers and they can use social media like WhatsApp to learn English both in class and outside 
of the classroom. For the researcher, this study helped to improve the knowledge and practice of English language teaching related to the use of ICT. For future researchers, the results of the study are expected to provide information and knowledge about students' perceptions and challenges of using WhatsApp to learn English and to conduct further research in the future that will focus on specific skills and ICT or social media. The results of the study are also expected to be a reference and information for the university to encourage English lecturers to be more creative and innovative in carrying out English teaching and learning activities, especially during this pandemic.

\section{METHOD}

The research was carried out at STAIN Teungku Dirundeng Meulaboh, where the researcher teaches and the university has an English department. In selecting the research participants, the researcher used a purposive sampling technique. The researcher selected all English-majored students of $2^{\text {nd }}$ semester from 12 people based on the consideration that they are actually learning English and are social media users on a daily basis so that they have plenty of experience in using social media for learning.

The research method in this research is qualitative research. The data collection technique explains how the researcher collects data related to the research focus. Interviews are used to find out more about students' perceptions and challenges in using WhatsApp. In this study, interviews were conducted directly because lectures had applied face-to-face in the New Normal period. In addition, the researcher chose semi-structured interviews to collect student responses. While conducting interviews, students answered three open-ended questions about their experiences, perceptions, and challenges using WhatsApp to learn English.

In the initial phase of the research process, interview questions were compiled for students. The researchers then conducted interviews in Indonesian so that students could answer the interview questions more freely. When interviewing students, researcher used a recording device to record the interview process. The interviews were conducted over three days and completed in around 10 to 15 minutes for each student. The researcher then transcribed the interview notes. After that, the interview data was collected and analyzed using a Miles and Huberman flow model. The model consists of several components to be analyzed, e.g. data reduction, data presentation, and conclusions. In data reduction, the researcher focused on choosing the parts to include in the interview record. The next phase is the presentation of the data. In this study, interview data were presented in narrative form. After the data is displayed, in the last phase, the researcher made conclusions based on the research questions.

\section{FINDING AND DISCUSSION}

The reseracher conducted interviews with students to find out their experiences, perceptions and challenges in learning English with WhatsApp. The analysis of the interview results, most of the respondents felt that their experience of learning English with WhatsApp was fun, comfortable, helpful, and easy to use.

"WhatsApp is not only used as a means of communication, but also as a medium for learning English, for example in listening classes. Lecturers often send audio files to groups via WhatsApp. Not only audio, video files and books in PDF format are often distributed by lecturers to groups. WhatsApp is often used during online learning and now in the New Normal era, WhatsApp is still used considering how easy and fast it is to send files as learning material." 
"In learning English, WhatsApp is also very helpful for the video and audio listening process during listening lessons. When playing audio or voice messages, the file will be heard clearly with the help of earphones. The volume on WhatsApp can also be adjusted according to your needs and the audio file can be played repeatedly."

Another statement also indicated how her experience with WhatsApp as a medium for learning English was not only in the listening class but also in other English classes such as speaking, reading and other subjects.

"During the speaking course, the lecturer sent us conversation videos for us to see and then we had to practice them. To hone our pronouncations, the lecturer gave examples of pronunciation through voice messages and then gave students the opportunity to practice them one by one through voice notes as well. In other courses, the lecturer also sent files either in the form of papers or powerpoint presentations as reading material and sometimes for presentation materials."

Based on multiple responses from students regarding their experience of using WhatsApp to learn English, students are accustomed to using WhatsApp as the students are already well-versed in technology and its applications, including WhatsApp, since this pandemic in the age of online learning. WhatsApp itself was still used in the New Normal era and is rated as the most used application by lecturers and students because sending files is easy and fast just with their smartphone.

In terms of students' perceptions of using WhatsApp when learning English, Some responses reflecting the students' perceptios are displayed. Most of them believe that using WhatsApp while learning English is considered effective and time-saving.

"WhatsApp application is very helpful in learning English as we don't have to waste time with this application. Why do I think if we write with stationery, for example, it will take a lot of time. WhatsApp is also the same as a laptop that has a keyboard for typing. The writing area is only narrower than that of a laptop."

"In particular, if there are classroom materials that the instructor was unable to explain to the students, the instructor can easily send the materials home for study. If there are problems understanding the reading material, the students can simply contact the instructor through the WhatsApp group. This makes WhatsApp viewed as an effective learning medium."

WhatsApp is not only effective and time-saving, it is also a motivating medium for speaking freely. This medium is perfect for students who often feel unsure about appearing in front of the class or are afraid of making mistakes using English.

"Using WhatsApp really helped me who always feel insecure. WhatsApp allows me to speak freely without feeling the fear or embarrassment that usually occurs when I see my friends' eyes when speaking in front of the class. The lecturer can also correct my mistakes immediately and they are saved in the chat room so that I can repeat them one day."

Based on multiple responses from students regarding their perception of using WhatsApp to learn English, students see WhatsApp as an effective application, saving time and motivating them to be braver and not be afraid of making mistakes.

When discussing the challenges students face when using WhatsApp to learn English, they mostly had similar reactions, namely issues with internet connection, internet quota, and storage on their device.

"The problem that most often occurs is the network that is less stable when learning takes place, even crashes when working on timed quizzes. The problem of the quota package used for learning is still under control. However, the internet quota needed by the Whatsapp application is less than other applications such as Google classroom or Zoom meeting. " 
"The use of WhatsApp actually does not cause too many obstacles, but it depends on the smartphone used. When the storage on the smartphone is full, sometimes all the files on WhatsApp will be lost. If it is not backed up, all important files are lost and cannot be restored."

\section{CONCLUSION}

WhatsApp is a popular mobile application that is widely used by students. Its popularity is attributed to the affordability of this application technology, which is not only free but also easy to use. Hence, its integrity in education has been debated by many authors with empirical research that has confirmed the significant achievements of language learners through the use of WhatsApp. These results are also supported by other researchers who focus on students' perceptions of using WhatsApp for good and satisfactory English learning. This study looked at EFL students' perceptions of use in English learning and showed relatively positive results. The findings included that this mobile application helped students improve their skills and that students had good attitudes towards learning English after using WhatsApp.

Despite its recognized benefits, using WhatsApp presents several challenges that can hinder the teaching and learning process. These challenges involve an internet connection and internet quota, although WhatsApp uses a small quota compared to other applications. The space on the device is also an obstacle for students to include files or study materials sent by the lecturers. The lecturers are therefore expected to take these conditions into account in order to make better use of the WhatsApp application so that they can help students learn English.

\section{ACKNOWLEDGEMENTS}

We would like to show our gratitude to those who helped us in this research, reviewer, editor, and the respondents.

\section{REFERENCES}

Afsyah, S. (2019). WhatsApp application in English Language Teaching (ELT) context: Media to describe people. Journal of Ultimate Research and Trends in Education, 1(1), 1-6. http://ojs.journal.unilak.ac.id/index.php/utamax

Ajid, L. H., Reni. R., Yunita, D. U., \& Dwi, S. (2018). The use of WhatsApp in collaborative learning to improve English teaching and learning process. International Journal of Research Studies in Educational Technology, 7(1), 29-35. https://doi.org/10.5861/ijrset.2018.3004

Alasmari, N. (2019). The use of WhatsApp in collaborative learning to improve the reading skill among university students: A case study of saudi students of English at the university of Jeddah. International Research in Higher Education, 4(4), 3651. https://doi.org/10.5430/irhe.v4n4p36

Bensalem, A. (2018). The impact of WhatsApp on EFL students' vocabulary learning. Arab World English Journal (AWEJ), 9(1), 23-38. https://dx.doi.org/10.24093/awej/vo19no1.2 
Budianto, F. \& Arifani, Y. (2021). Utilizing WhatsApp-driven learning during Covid19 outbreak: EFL users' perceptions and practices. Computer Assisted Language Learning Electronic Journal, 22(1), 272-289.

Cetinkaya, L. (2017). The impact of WhatsApp use on success in education process. International Review of Research in Open and Distributed Learning, 18(7), 59-74.

Dewi, S. R. (2019). Utilizing WhatsApp application for teaching integrated English (a case study at university of technology Yogyakarta). Refleksi Edukatika : Jurnal Ilmiah Kependidikan, 9(2), 164-171. http://jurnal.umk.ac.id/index.php/RE

Famurlasih, S. (2020). Students' experiences in using online learning applications due to covid-19 in English classroom. SiLeT, 1(2), 112-121. https://doi.org/10.46627/silet.v1i2.40

Hamad, M. M. (2017). Using WhatsApp to enhance students' learning of English language "experience to share". Higher Education Studies, 7(4), 74-87. http://doi.org/10.5539/hes.v7n4p74

Jasrial, D. (2018). Utilizing WhatsApp application for teaching English language: Why and how? International Seminar BKS-PTN Wilayah Barat Fields of Language, Literature, Arts, and Culture, 1(1), 151-157.

Kheryadi. (2017). The implementation of "WhatsApp" as a media of English language teaching. Loquen, 10(2), 1-13.

Linda \& Ri'aeni, I. (2018). Whatsapp messenger as a mobile media to learn writing for EFL Students. JIKE, 1(2), 156-165.

Muslem, A., Yusuf, Y. Q., \& Juliana, R. (2018). Perceptions and barriers to ICT use among English teachers in Indonesia. Teaching English with Technology, 18(1), 323. https://www.ceeol.com/search/article-detail?id=606504

Napratilora, M., Lisa, H., \& Bangsawan, I. (2020). Using WhatsApp as a learning Media in teaching reading. J. Mitra PGMI, 6(2), 116-125.

Nihayati, A. \& Indriani, L. (2021). EFL students' perspective on Whatsapp as media of online teaching and tearning in Covid-19 pandemic. Journal of Research on Language Education, 2(1), 44-52. https://ejurnal.teknokrat.ac.id/index.php/JoRLE/index

Nurazizah, H., Frihatin, L. Y., \& Sugiarto, B. R. (2019). WhatsApp voice note in speaking Class. Journal of English Education and Teaching (JEET), 3(3), 343-360. https://doi.org/10.33369/jeet.3.3.343-360

Pratama, H., Azman, M. N. A., Kassymova, G. K., \& Duisenbayeva, S. S. (2020). The trend in using online meeting applications for learning during the period of pandemic Covid-19: A literature review. Journal of Innovation in Educational and Cultural Research, 1(2), 58-68. https://doi.org/10.46843/jiecr.v1i2.15

Setyowati, Y. (2019). Let's listen through WhatsApp: An energizing listening exercise in EFL class. Journal of Physics: Conference Series, 1179(012052), 1-5. https://doi.org/10.1088/1742-6596/1179/1/012052 
Suadi. (2021). Students' perceptions of the use of zoom and whatsApp in ELT amidst covid19 pandemic. SALEE: Study of Applied Linguistics and English Education, 2(1), 51-64. https://doi.org/10.35961/salee.v2i01.212

Ta'amneh, M. A. A. (2017). The effect of using WhatsApp Messenger in learning English language among university students. International Research in Education, 5 (1), 143151. http://dx.doi.org/10.5296/ire.v5i1.10801

Thaariq, Z. Z. A. (2020). The use of social media as learning resources to support the new normal. Teknodika, 80-93. https://doi.org/10.20961/teknodika.v18i2.42181

Umar. (2021). Implementation of e-learning on the teaching English as global language in the pandemic-era. Jurnal Inovasi Penelitian, 1(10), 2095-2098. 